\title{
The Effects of Poly(vinyl acetate) Filled with Nanoday and Cellulose Nanofibrils on Adhesion Strength of Poplar and Scots Pine Wood
}

\section{Utjecaj poli(vinil acetata) s punilom od nanočestica gline i celuloznih nanovlakana na čvrstoću lijepljenja drva topole i običnog bora}

\author{
Original scientific paper • Izvorni znanstveni rad \\ Received-prispjelo: 8. 12. 2014. \\ Accepted-prihvaćeno: 29. 1. 2016. \\ UDK: $630 * 824.31 ; 630 * 824.323 ; 630 * 824.44 ; 674.031623 .234 ; 764.032 .475 .442$ \\ doi:10.5552/drind.2016.1441
}

\begin{abstract}
Cellulose nanofibrils (CNFs) and nano clay (NC) were selected to determine the effects of different fillers on the characterization of poly(vinyl acetate) (PVA). Characterizations of the PVA composites obtained were studied by thermogravimetric analysis (TGA/DTG), scanning electron microscopy (SEM) and the lap joint shear strength (LJSS). The morphological studies revealed that some clumpings were observed in SEM images for $1 \%, 2 \%$, and $4 \%$ wt loadings for CNFs and NC fillers. Dispersed particle orientation morphology and the wave sheets appear to be uniformly distributed on the surface of the composites. Seen as the effects of fillers on the thermal stability, the results showed that NC has a greater effect than CNFs, depending on the loading rates of fillers. Lap joint shear strength generally increased after adding CNFs and NC to PVA matrix. Thus, it can be said that PVA has higher bonding performance and can be used in applications requiring higher bonding strength.
\end{abstract}

Key words: Poly(vinyl acetate), cellulose nanofibrils (CNFs), nano clay (NC), nanoparticles filled composites, adhesion

SAŽETAK • Za istraživanje utjecaja različitih punila na svojstva poli(vinil acetata) (PVA) odabrana su celulozna nanovlakna (CNFs) i nanočestice gline (NC). Svojstva PVA kompozita istražena su termoanalizom (TGA/DTG), skeniranjem elektronskim mikroskopom (SEM) i određivanjem smicajne čvrstoće spoja (LJSS). Morfološke su studije pokazale da su skupine čestica zabilježene na SEM slikama pri težinskom udjelu CNFs i NC punila od 1, 2 i $4 \%$. Raspršena morfologija orijentacije čestica i valovi ravnomjerno su raspoređeni na površini kompozita. Iz analize utjecaja punila na termičku stabilnost može se zaključiti da NC ima veći utjecaj od CNFs-a, ovisno o težinskom udjelu punila. Smicajna čvrstoća spoja općenito se povećava nakon dodavanja CNFs i NC punila na

\footnotetext{
${ }^{1}$ Authors are assistant professors at Bartin University, Faculty of Forestry, Department of Forest Industrial Engineering, Bartin, Turkey. ${ }^{2} \mathrm{Au}-$ thor is professor at Luleå University of Technology, Wood Technology, Skellefteå, Sweden.

Autori su docenti Sveučilišta u Bartinu, Šumarski fakultet, Odjel za industrijsku preradu drva, Bartin, Turska. ${ }^{2}$ Autor je profesor Tehnološkog sveučilišta u Luleåu, Drvna tehnologija, Skellefteå, Švedska.
} 
PVA matricu. Prema tome, može se reći da PVA s CNFs i NC punilom ima veću učinkovitost lijepljenja i može se primijeniti u aplikacijama koje zahtijevaju veću čvrstoću lijepljenja.

Ključne riječi: poli(vinilni acetat), celulozna nanovlakna (CNFs), nanočestice gline (NC), kompoziti s punilom od nanočestica, adhezija

\section{INTRODUCTION}

1. UVOD

Nano particle filled composites, a class of nanostructured materials composed of various polymers and fillers, have superior physical, mechanical and other properties when compared with neat polymers (Rhim and Ng, 2007; Zhao et al., 2008; Shchipunov, 2012). Various polymer matrixes are generally used in the production of polymer with nano fillers. Therefore, to obtain more environmentally friendly materials that decrease dependence on fossil-based resources, in recent years, different biodegradable polymers such as PVA have been developed. As the properties of such polymers are sometimes inferior to those of commercial non-biodegradable polymers, the composites filled with different fillers of such biodegradable polymers have been developed to obtain high performance in application area. For example the use of the composites for packaging and other applications has been strongly limited because of the poor barrier properties and weak mechanical properties. For this reason, biodegradable polymers have frequently been blended with other synthetic polymers and various fillers, or less frequently, chemically modified with the aim of extending their application (Guilbert et al., 1997; Petersen et al., 1999).

Polymers that are increasingly used in composite manufacturing to replace non-biodegradable polymers include starch, cellulose, polylactic acid, polyhydroxy alkanoates, pectin, chitosan, collagen among others (Mittal, 2011). To prepare biodegradable composites, many nano fillers, such as nanoclay, starch, cellulose, and carbon nanotubes, have been used. The composites have been prepared via several methods, such as in situ polymerization, solution exfoliation, and melt intercalation (Dennis et al., 2001; Zeng et al., 2005).

$\mathrm{NC}$ and CNFs are bio-fillers commonly used to produce biodegradable composites. NC has a unique structure and properties and a very high elastic modulus as compared to many biodegradable fillers. The higher elastic modulus enables NC to improve mechanical properties of polymers by carrying a significant portion of the applied stress (Zeng et al., 2005; Fornes and Paul, 2003). CNFs, which was obtained from cellulose fibers, is a natural polymer with the chemical formula $\left(\mathrm{C}_{6} \mathrm{H}_{10} \mathrm{O}_{5}\right) \mathrm{n}$. It is a polysaccharide consisting of a linear chain of several hundred to more than 10,000 $\beta(1 \rightarrow 4)$ linked D-glucose units (Klemm et al., 2005; Nishiyama, 2002). CNFs have a higher modulus and strength because of microfibrillar spiral angle (Ichhaporia, 2008). The linear chains have alcoholic hydroxyl groups. The hydroxyl groups form inter-molecular and intra-molecular hydrogen bonds with the macrostructure of cellulose. CNFs are used as a reinforcing agent in polymer composites because they offer many important advantages and strong mechanical properties (Mohanty et al., 2005).

PVA is a widely used, cheap, biodegradable adhesive, but it has low adhesion strength (Kaboorani and Riedl, 2011). The aim of this study was to improve the adhesion properties of PVA with NFCs and NC. CNFs, with sustainability, industrial ecology, and green chemistry, and $\mathrm{NC}$, with its unique structure and properties and very high elastic modulus, were selected to prepare the biodegradable composites in this study. PVA was used to prepare the biodegradable composites. The properties of the composites prepared with PVA and nano fillers at different loading rates $(1 \%, 2$ $\%$, and $4 \%$ ) were investigated by using thermogravimetric analysis (TGA/DTG), morphological characterization with scanning electron microscopy (SEM), and lap joint shear strength (LJSS).

\section{MATERIALS AND METHODS}

\section{MATERIJAL I METODE}

\subsection{Materials}

2.1. Materijali

Cellulose nanofibrils (CNFs) were supplied by J. Rettenmaier \& Sohne (JRS). NC was purchased from Nanocor, Canada. The NC, which was supplied as micro fine powders under the "I" series designation, was ready for use directly into the resin system. PVA, having a 1200 polymerization degree and a $90 \%$ hydrolysis level, was purchased from Chemical Enterprise Caparol and used to prepare the composites. Poplar and Scots pine wood were used to determine the lap joint shear strength. They were cut to $20 \times 150 \times 5$ $\mathrm{mm}$ according to BS EN 205 and, before bonding, the samples were put into the condition chamber at $20{ }^{\circ} \mathrm{C}$ with relative humidity of $60 \%$ for a week.

\subsection{Method}

\subsection{Metode}

CNFs and NC filled PVA composites were prepared with the solution method using various loading rates of nano particles as show in Table 1.

Particles were first dispersed in distilled water (1, 2, $4 \mathrm{~g}$ filler/10 $\mathrm{ml} \mathrm{DI}$ ) by mechanical stirring at $2000 \mathrm{rpm}$ for $5 \mathrm{~min}$. The suspensions obtained were mixed with PVA. The stirring was started with $1000 \mathrm{rpm}$ for $1 \mathrm{~min}$ and was increased up to $2000 \mathrm{rpm}$ and was continued for $20 \mathrm{~min}$ to achieve a viscous solution. The mixture was degassed for approximately 30 minutes in an oven without vacuum at $40{ }^{\circ} \mathrm{C}$. It was cast on an aluminum plate and kept for one week until it was completely dried. All formulations were prepared with the same process.

The morphology of the surfaces of the composite films was observed with an environmental scanning electron microscopy (ESEM), the Phillips Electroscan 
Table 1 Experimental design

Tablica 1. Dizajn eksperimenta

\begin{tabular}{|l|c|c|c|}
\hline Samples / Uzorci & $\begin{array}{c}\text { Matrix } \\
\text { Matrica, \% }\end{array}$ & CNF, \% & NC, \% \\
\hline Pure PVA & 100 & - & - \\
\hline PVA+1 \% NC & 99 & - & 1 \\
\hline PVA+2 \% NC & 98 & - & 2 \\
\hline PVA+4 \% NC & 96 & - & 4 \\
\hline PVA+1 \% CNF & 99 & 1 & - \\
\hline PVA+2 \% CNF & 98 & 2 & - \\
\hline PVA+4 \% CNF & 96 & 4 & - \\
\hline
\end{tabular}

2020, with an accelerating voltage of $5 \mathrm{kV}$. The surface of all samples was sputter-coated with gold using a Denton sputter coater for enhanced conductivity. The thermal stability of the composites was investigated using a thermogravimetric/differential thermal analysis (TGA/DTG) (Perkin Elmer, TA Instruments, USA). The samples were heated from $25{ }^{\circ} \mathrm{C}$ to $600{ }^{\circ} \mathrm{C}$ with a heating rate of $10^{\circ} \mathrm{C} / \mathrm{min}$ and a nitrogen flow of 100 $\mathrm{mL} / \mathrm{min}$. The shear tests were performed using a testing machine with load cell 1 of $\mathrm{kN}$ (Utest Inc., Turkey). The cross head speed was $5 \mathrm{~mm} / \mathrm{min}$. The dimension of wood samples was $10 \mathrm{~mm}$ in width and $150 \mathrm{~mm}$ in length. The bonding area of the samples was calculated before the test ( $220 \mathrm{~g}$ adhesive was used for $1 \mathrm{~m}^{2}$ surface area) and the application was made by using a brush. Samples for tensile testing were prepared and tested according to TS EN 392:1999 and ISO 12579:2007. Utest machine was used to determine the lap shear strength, deformation and $F_{\max }$. All data was automatically obtained with the utest machine software.

\section{RESULTS AND DISCUSSION 3. REZULTATI I RASPRAVA}

The composites prepared with CNFs and $\mathrm{NC}$ was found to be having different effects on morphological, mechanical and thermal properties. The SEM micrographs of composite surfaces with different loadings ( $1 \%, 2 \%$ and $4 \% \mathrm{wt}$ ) of CNFs and NC are shown in Fig. 1 and Fig. 2. The images of composites show dispersed particle orientation morphology and the wave sheets appear to be uniformly distributed on the surface of composites. When the loading rates were increased from $1 \%$ to $4 \%$ for CNFs in Fig. 1, clumping for $1 \%$, $2 \%$, and $4 \% \mathrm{wt}$ loadings due to the strong hydrogen bonding affinity was observed. After increasing the loading rate of $4 \% \mathrm{wt}$, the dispersion of CNFs deteriorated. For NC, partially agglomerated clay particles were also observed in the polymer matrix, as seen in Fig. 2.

As seen in Fig. 1, the aggregated nanofibrils appear as white dots in different parts of the composites. In Fig. 1, 2 \% CNFs was homogenously dispersed in the PVA; nevertheless, a few aggregated fibrils were observed in the SEM picture. Clumping and aggregated parts in the $4 \%$ CNFs were higher than composites with $1 \%$ and $2 \%$ CNFs. This status can be said to arise due to the hydrogen bonding among the cellulose nanofibrils and/or inadequate mixing or increasing of viscosity in the preparation of composites. As a result,

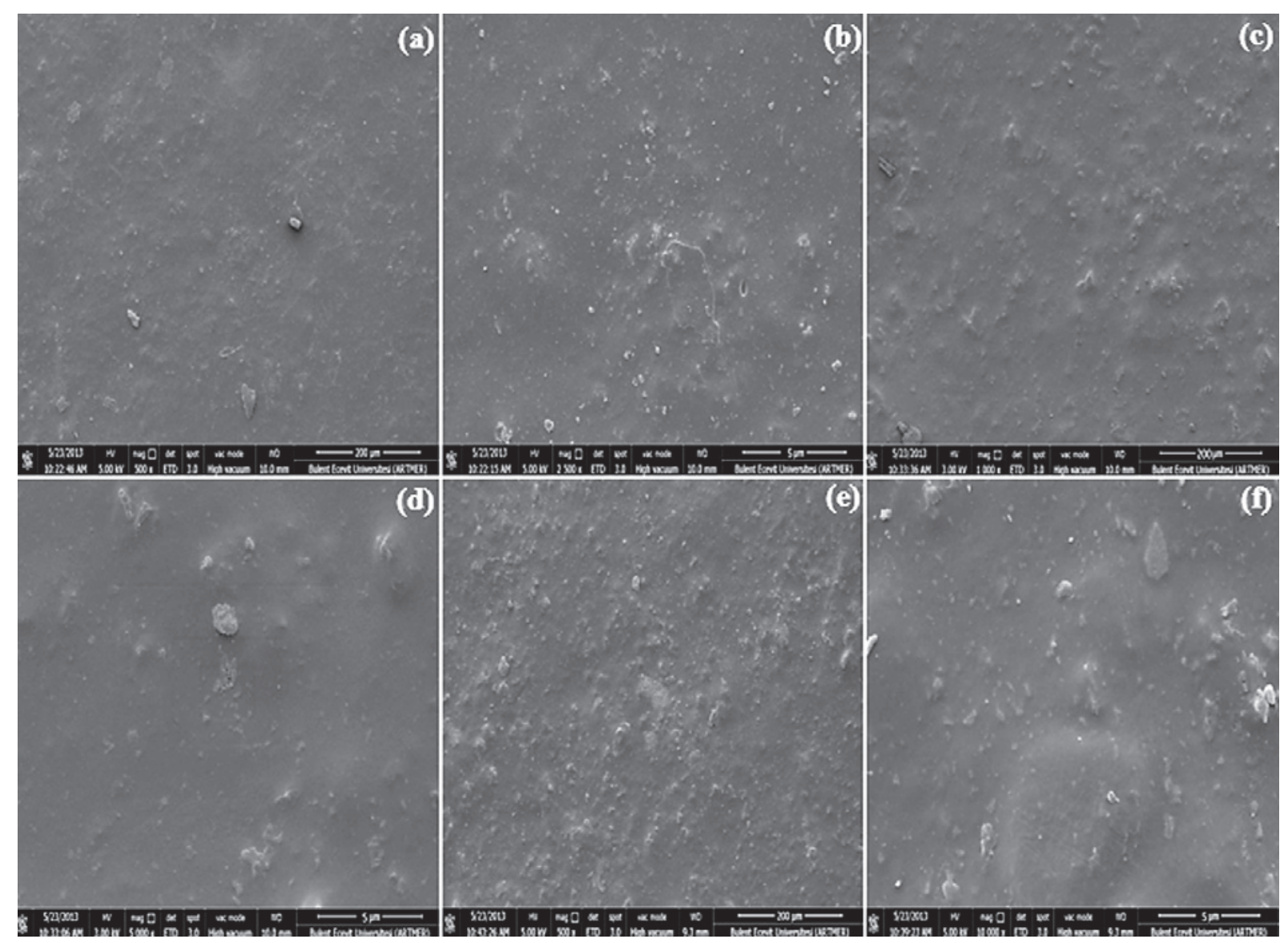

Figure 1 SEM images of PVA composites (a and b) $1 \% \mathrm{CNFs}$, (c and d) $2 \% \mathrm{CNFs}$, and (e and f) $4 \% \mathrm{CNFs}$

Slika 1. SEM slike PVA kompozita (a i b) s $1 \%$ CNFs-a, (c i d) $2 \%$ CNFs-a i (e i f) $4 \%$ CNFs-a 


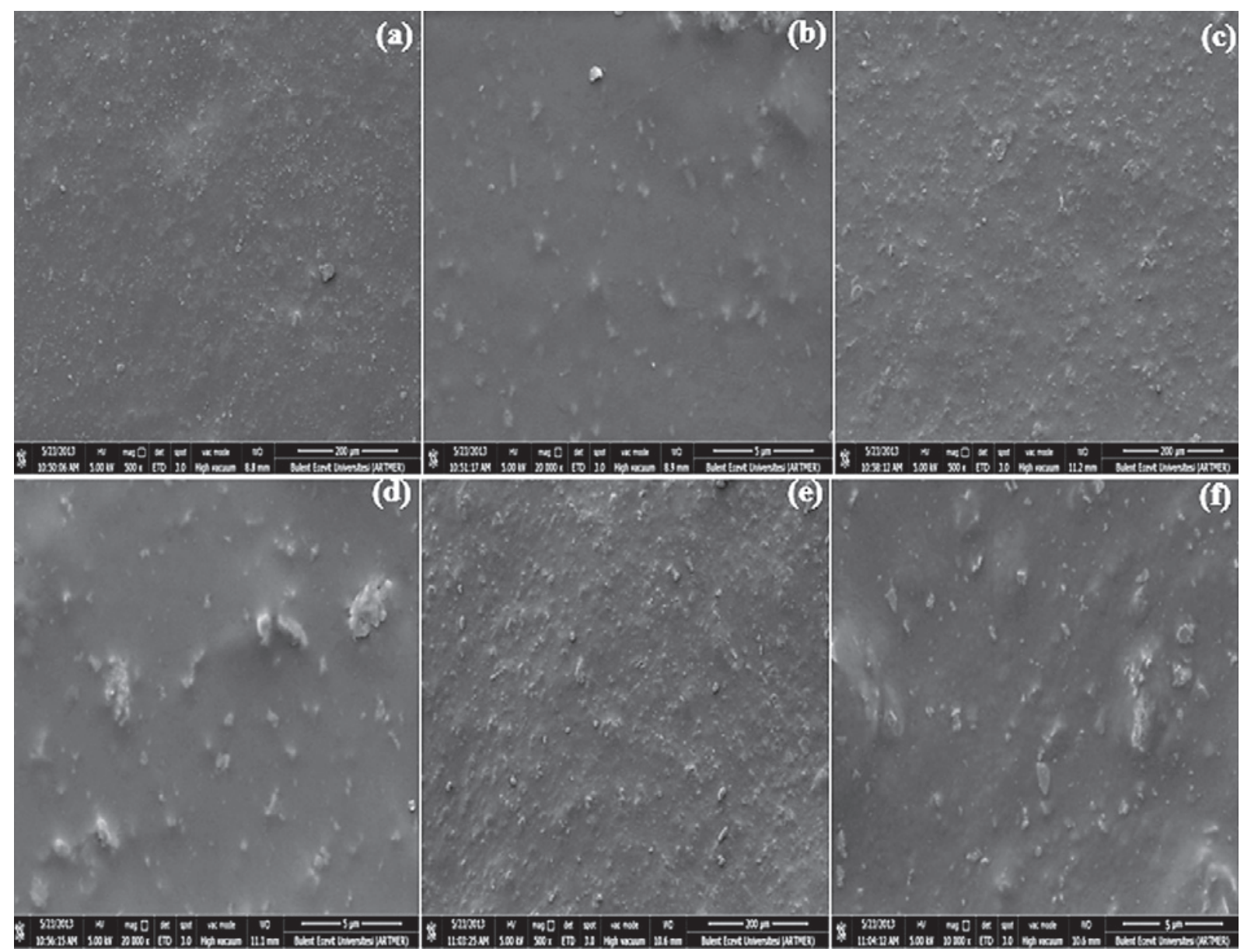

Figure 2 SEM images of PVA composites (a and b) $1 \% \mathrm{NC}$, (c and d) $2 \% \mathrm{NC}$, and (e and f) $4 \% \mathrm{NC}$ Slika 2. SEM slike PVA kompozita (a i b) s $1 \% \mathrm{NC}-\mathrm{a}$, (c i d) $2 \% \mathrm{NC}$-a i (e i f) $4 \% \mathrm{NC}$-a

clumping was observed in all the composites with CNFs. According to Fig. 2, the dispersion to all loading rates of $\mathrm{NC}$ in the composites was more homogenous than those of composites with CNFs. In SEM images, the clumping for $1 \%, 2 \%$, and $4 \%$ wt CNFs loadings was observed due to the strong hydrogen bonding affinity. For NC, partially agglomerated clay particles were also observed in the polymer matrix.

Qua et al. (2009) studied nanocomposites made of cellulose nanofibers with $110 \mathrm{~nm}$ length and PVA. SEM images showed that cellulose fibers appear as white dots on the fracture surface of PVA nanocomposites. There is some cellulose aggregation in PVA as a result of the high level of compatibility and interaction between the hydrophilic crystalline cellulose nanofibers and the PVA matrix. Lopez-Suevos et al. (2006) investigated the properties of PVA composites with cellulose nanofibrils. Their results revealed cellulose fibril aggregates in the matrix.

Mallakpour and Dinari (2013) worked on synthesis and properties of biodegradable poly (vinyl alcohol) / organo-NC bionanocomposites (BNCs). The SEM images of PVA/organo-clays BNCs show a flake-like structure and smooth morphology. The matrix is filamentous with interconnecting pores. However, increasing the NC content leads to a decrease in the number and size of the pores. This morphological change can be attributed to the re-ordered crystalline phase of the PVA matrix, causing a packed network. The thermal stability of composites was investigated using TGA/DTG separately under nitrogen. The data obtained are shown in Fig. 3 and Table 2. As seen in Fig. 3, there are three steps

Table 2 Summary data of thermal stability of biodegradable PVA nanocomposites Tablica 2. Ukupni rezultati termičke stabilnosti biorazgradivih PVA kompozita

\begin{tabular}{|c|c|c|c|c|c|}
\hline \multirow[b]{2}{*}{ Samples / Uzorci } & \multirow{2}{*}{$\begin{array}{l}T_{10 \%} \\
{ }^{\circ} \mathrm{C}\end{array}$} & \multirow{2}{*}{$\begin{array}{l}T_{50 \%} \\
{ }^{\circ} \mathrm{C}\end{array}$} & \multirow{2}{*}{$\begin{array}{c}\text { DTG }_{\max } \\
{ }^{\circ} \mathrm{C}\end{array}$} & \multicolumn{2}{|c|}{ Maximum decomposition / Maksimalna razgradnja } \\
\hline & & & & $\begin{array}{c}\text { Residue / Ostatak } \\
\% / \text { min. }\end{array}$ & $\begin{array}{c}\text { Mass loss / Gubitak mase } \\
\%\end{array}$ \\
\hline Pure PVA & 309.1 & 418.2 & 332.3 & 8.25 & 91.75 \\
\hline $\mathrm{PVA}+1 \% \mathrm{CNF}$ & 307.6 & 418.5 & 334.5 & 9.12 & 90.88 \\
\hline $\mathrm{PVA}+2 \% \mathrm{CNF}$ & 310.8 & 419.3 & 337.1 & 13.56 & 86.44 \\
\hline $\mathrm{PVA}+4 \% \mathrm{CNF}$ & 311.2 & 419.8 & 336.5 & 24.32 & 75.68 \\
\hline $\mathrm{PVA}+1 \% \mathrm{NC}$ & 309.3 & 415.1 & 333.6 & 30.51 & 69.49 \\
\hline $\mathrm{PVA}+2 \% \mathrm{NC}$ & 309.6 & 425.1 & 335.4 & 32.32 & 67.68 \\
\hline $\mathrm{PVA}+4 \% \mathrm{NC}$ & 310.54 & 427.2 & 336.2 & 34.53 & 65.47 \\
\hline
\end{tabular}




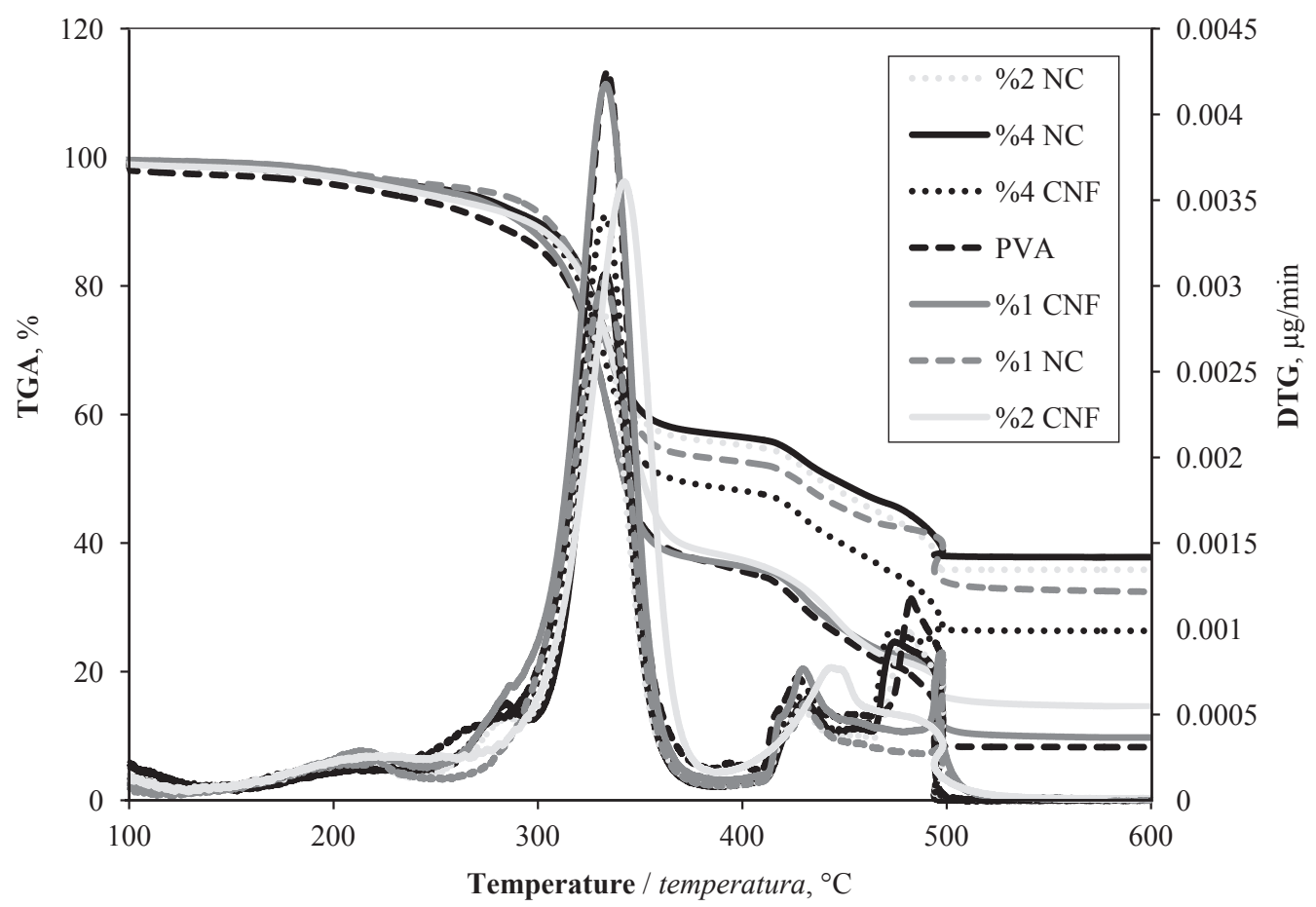

Figure 3 TGA curves of NC and CNFs reinforced PVA composites

Slika 3. TGA krivulje PVC kompozita pojačanih nanočesticama gline (NC) i celuloznim nanovlaknima (CNFs)

of thermal degradation of the composites in the temperature range of $100{ }^{\circ} \mathrm{C}-600{ }^{\circ} \mathrm{C}$.

The temperature range for the first step of thermal degradation $\left(T_{\mathrm{d}}\right)$ is $100{ }^{\circ} \mathrm{C}-200{ }^{\circ} \mathrm{C}$. This corresponds to the loss of water from the composites. The temperature range for the second step of $T_{\mathrm{d}}$ is $250{ }^{\circ} \mathrm{C}-400{ }^{\circ} \mathrm{C}$. This corresponds to the decomposition of fillers ( $\mathrm{NC}$ and CNFs) and weight loss of PVA from the composites. There is an additional third step of $T_{\mathrm{d}}$ in the temperature range of $400{ }^{\circ} \mathrm{C}-600{ }^{\circ} \mathrm{C}$ under nitrogen. This might be due to oxidation of partially decomposed fillers under nitrogen. According to the TGA analysis, adding of fillers improved the thermal stability and thermal stability of PVA matrix was found to increase with filler reinforcement. Similar results for different types of composite films have been reported (Wang et al., 2006; Tunc et al., 2007; Kumar et al., 2010). The lap joint shear strength was used to evaluate the bonding properties of PVA composites. The test was conducted on both poplar and pine woods. The lap shear joint strength of the composite woods is shown in Fig. 4. A common and useful style of bonding testing is the lap shear joint strength test.

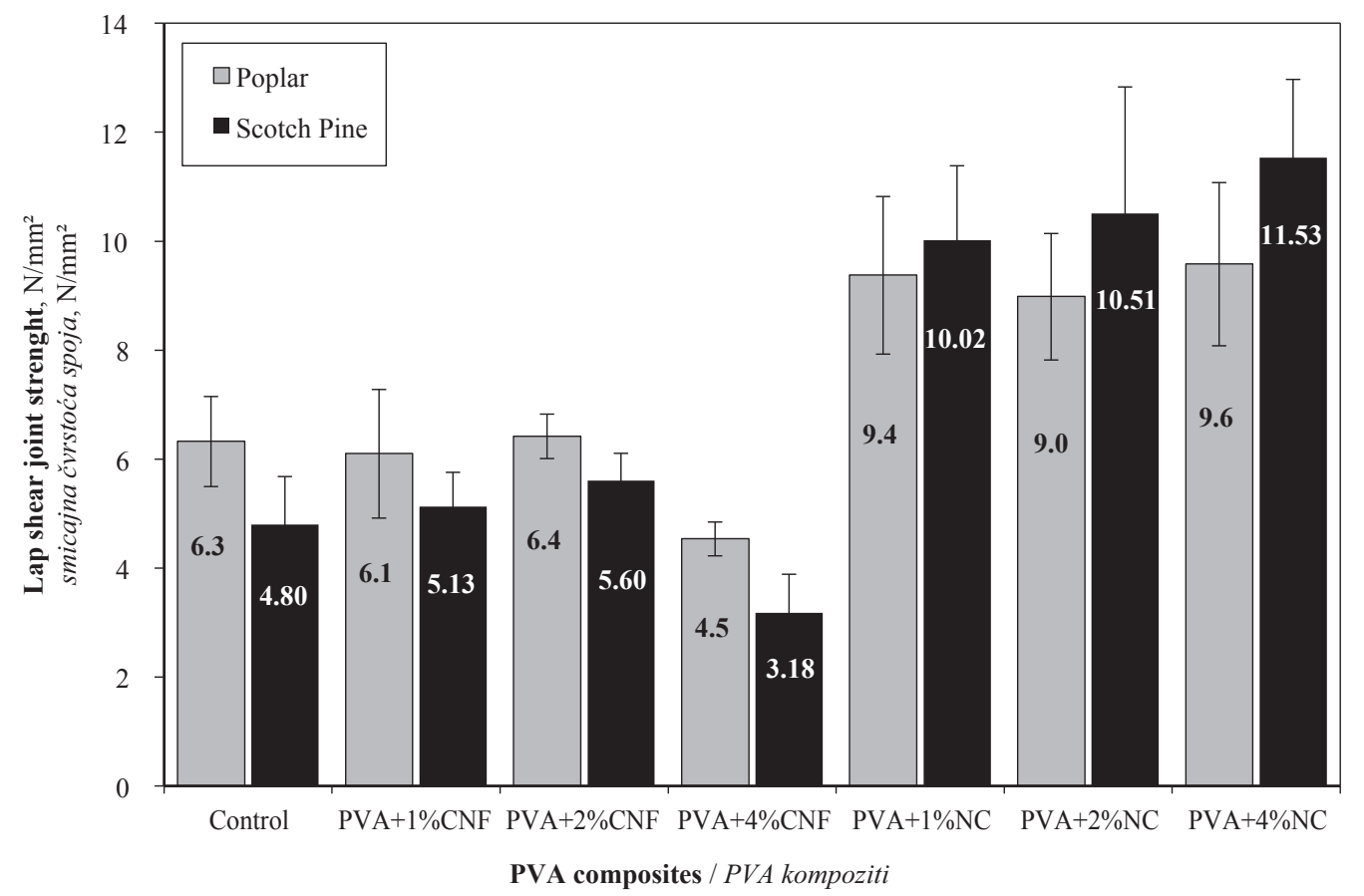

Figure 4 Lap shear joint strength of PVA composites

Slika 4. Smicajna čvrstoća spoja izvedenog PVA kompozitnim ljepilom 


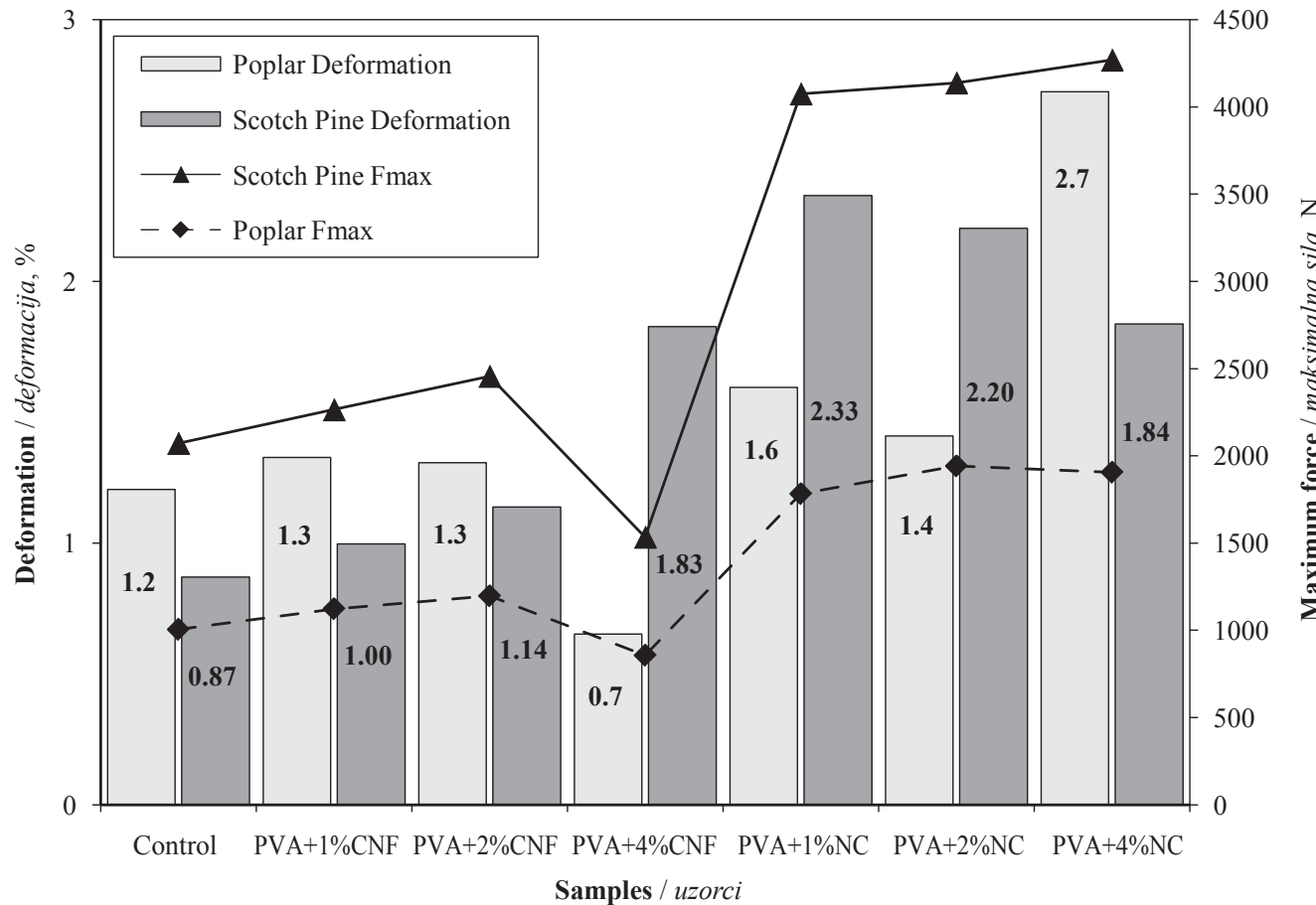

Figure 5 Deformation and $F_{\max }$ of PVA nanocomposites during tension test

Slika 5. Deformacija i $F_{\max }$ PVA nanokompozita tijekom tenzijskog testa

This test is both simple and economical in application. The test is important because of the conditions to which structural adhesives are often subjected in service. Adding NC to the polymer matrix had a higher improving effect on lap shear strength than adding CNFs. While the effect of CNFs was lower than NC on poplar and Scots pine wood.

Lap shear joint strength increased with adding 2 $\%$ CNFs on both woods, $1 \%$ CNFs increased only with Scotch pine wood. However, $4 \%$ loading rates of CNFs decreased the lap shear strength of both woods. The maximum increase of CNFs was $1.5 \%$ for poplar wood and $16.7 \%$ for pine wood. Lap shear strength decreased at a different ratio for the $1 \%$ and $4 \%$ CNFs loadings. Adding of CNFs to the PVA matrix has a similar effect on both poplar wood and Scots pine wood. Seen as the reinforcing effect of NC, lap shear strength of both woods increased as loading rates rose from $1 \%$

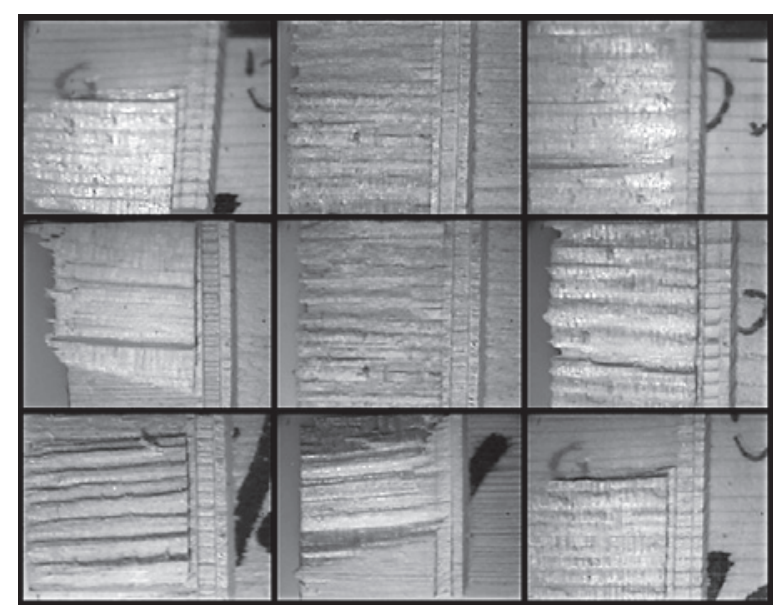

Figure 6 Failure types on wood samples during tension test Slika 6. Vrste loma na uzorcima drva tijekom tenzijskog testa to $4 \%$. The maximum increase was $52.4 \%$ in the $4 \%$ for poplar wood and $140 \%$ in the $4 \%$ for Scots pine wood. The significant improvement in lap shear strength was achieved with adding of NC to both wood types. The different trends between woods can be attributed to anatomical structure. The significant improvement in the lap shear strength provided with $\mathrm{NC}$ is due to enlargement of the interaction area or enhanced adhesion strength per interaction area.

With an increase of CNFs and NC loadings added to PVA from $1 \%$ to $4 \%, F_{\max }$ and deformation of both woods first increased and then decreased. Lap shear strength increased for the $1 \%$ and $2 \%$ CNFs loadings and decreased for $4 \%$ loading. Seen as the reinforcing effect of NC, lap shear strength of both woods increased as loading rates rose from $1 \%$ to $4 \%$. Adding NC to the polymer matrix had a higher effect than adding CNFs. This study demonstrated that adding of the NC

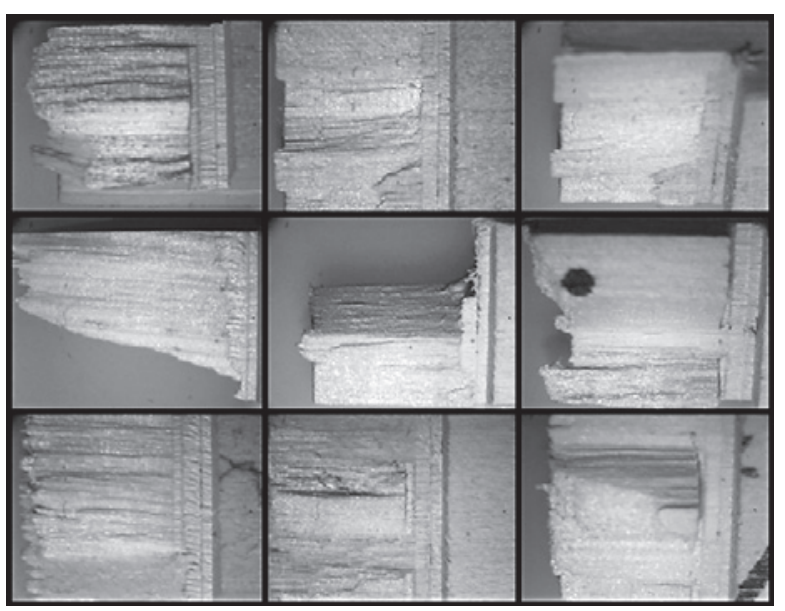


to PVA matrix improved the adhesion performance. The improving effect of CNFs was less than NC.

Kaboorani and Riedl (2011) researched the effects of adding NC on the performance of PVA in the dry and wet state. The results showed that in the dry state, shear strength significantly improved and improvement rates rose from $7 \%$ to $20 \%$. In the wet state, as loading $\mathrm{NC}$ was increased, marked improvements in shear strength were achieved, as high as $53 \%$. The $F_{\text {max }}$ and deformation value are given for both wood types in Fig. 5. The fracture surfaces of the samples are shown in Fig. 6.

After inspecting the fracture surface of the lap shear samples, all the samples had ruptures in the wood.

\section{CONCLUSION 4. ZAKLJUČAK}

The PVA composites were successfully prepared with suspensions of $\mathrm{CNF}$ and $\mathrm{NC}$ by using the solution method. According to the results, adding of $\mathrm{NC}$ and CNFs to PVA affected all of the properties of polymer matrix. The effect of NC on the PVA composites was found to be higher than the effect of CNFs. Thermal stability of composites improved by adding of $\mathrm{NC}$ and CNFs and $\mathrm{DTG}_{\max }$ increased depending on filler type. Morphological evaluations by SEM showed that the particle dispersion is a function of fillers and loading levels, and that there is a direct link between the quality of dispersion and the properties of composites. As a result, the PVA composites can be said to have higher performance than pure PVA polymer. Thus, high durable joints can be obtained in the application areas.

\section{Acknowledgments - Zahvala}

This study was supported by the Department of the Scientific Research Project (BAP2012-2-68) of Bartin University. The authors thank Assoc. Prof. Dr. Mehmet Akyuz and the staff of the Bulent Ecevit University Central Laboratory for the thermal and morphological testing of the samples.

\section{REFERENCES}

\section{LITERATURA}

1. Dennis, H. R.; Hunter, D. L.; Chang, D.; Kim, S.; White, J. L.; Cho, J. W.; Paul, D. R., 2001: Effect of melt processing conditions on the extent of exfoliation in organo clay based nanocomposites. Polymer, 42: 9513-9522 http://dx.doi.org/10.1016/S0032-3861(01)00473-6.

2. Fornes, T. D.; Paul, D. R., 2003: Modeling properties of nylon 6/clay nanocomposites using composite theories. Polymer, 44: 4993-5013 http://dx.doi.org/10.1016/S0032-3861(03)00471-3.

3. Guilbert, S.; Cuq, B.; Gontard, N., 1997: Recent innovations in edible and/or biodegradable packaging materials. Food Additives \& Contaminants: Part A, 14: 741-751 http://dx.doi.org/10.1080/02652039709374585.

4. Ichhaporia, P. K., 2008: Composites from Natural Fibers. $\mathrm{PhD}$, North Carolina State University, North Carolina, USA.
5. Kaboorani, A.; Riedl, B., 2011: Effects of adding nanoclay on performance of polyvinyl acetate (PVA) as a wood adhesive. Cellulose, 14: 419-425 http://dx.doi.org/10.1016/j.compositesa.2011.04.007.

6. Klemm, D.; Heublen, B.; Fink, H. P.; Bohn, A., 2005: Cellulose: Fascinating biopolymer and sustainable raw material, Angewandte Chemie International Edition, 44: 3358-3393 http://dx.doi.org/10.1002/chin.200536238.

7. Kumar, P.; Sandeep, K. P.; Alavi, S.; Truong, V. D.; Gorga, R. E., 2010: Preparation and characterization of bionanocomposites films based on soy protein isolate and montmorillonite using melt extrusion. Journal of Food Engineering, 100: 480-489 http://dx.doi.org/10.1016/j.jfoodeng.2010.04.035.

8. Lopez-Suevos, F.; Frazier, C. E., 2006: Fracture cleavage analysis of PVAc latex adhesives: Influence of phenolic additives. Holzforschung, 60: 313-317

http://dx.doi.org/10.1515/HF.2006.050.

9. Mallakpour, S.; Dinari, M., 2013: Chiral bio-nanocomposites based on thermally stable poly(amide-imide) having phenylalanine linkages and reactive organo-clay containing tyrosine amino acid. Amino Acids, 44: 10211029 http://dx.doi.org/10.1007/s00726-012-1436-2.

10. Mittal, V., 2011: Nanocomposites with Biodegradable Polymers: Synthesis, Properties, and Future Perspectives. Chapter: Bio-nanocomposites: future high-value materials. Oxford University Press, 400 pp., USA http:// dx.doi.org/10.1093/acprof:oso/9780199581924.001.0001.

11. Mohnty, A. K.; Misra, M.; Drzal, L. T.; Selke, S. E.; Harte, B. R.; Hinrichsen, G., 2005: Natural Fibers, Biopolymers, and Biocomposites: An Introduction. CRC Press, 896 pp., USA http://dx.doi.org/10.1201/9780203508206.

12. Nishiyama, Y.; Langan, P.; Chanzy, H., 2002: Crystal Structure and Hydrogen-Bonding System in Cellulose IB from Synchrotron X-ray and Neutron Fiber Diffraction. Journal of the American Chemical Society, 124: 90749082 http://dx.doi.org/10.1021/ja037055w.

13. Petersen, K.; Nielsen, P. V.; Bertelsen, G.; Lawther, M.; Olsen, M. B.; Nilssonk, N. H., 1999. Potential of biobased materials for food packaging. Trends Food Science Technology, 10: 52-68 http://dx.doi.org/10.1016/S0924-2244(99)00019-9.

14. Qua, E. H.; Hornsby, P. R.; Sharma, H. S. S.; Lyons, G.; McCall, R. D., 2009. Preparation and characterization of poly (vinyl alcohol) nanocomposites made from cellulose nanofibers. Journal of Applied Polymer Science, 113: 2238-2247 http://dx.doi.org/10.1002/app.30116.

15. Rhim, J. W.; Ng, P. K. W., 2007: Natural biopolymerbased nanocomposites films for packaging applications. Critical Reviews in Food Science and Nutrition, 47: 411433 http://dx.doi.org/10.1080/10408390600846366.

16. Shchipunov, Y., 2012: Bionanocomposites: Green sustainable materials for the near future. Pure and Applied Chemistry, 84: 2579-2607 http://dx.doi.org/10.1351/PAC-CON-12-05-04.

17. Tunc, S.; Angellier, H.; Cahyana, Y.; Chalier, P.; Gontard, N.; Gastaldi, E., 2007: Functional properties of wheat gluten/montmorillonite nanocomposites films processed by casting. Journal of Membrane Science, 289: 159-168 http://dx.doi.org/10.1016/j.memsci.2006.11.050

18. Wang, S.; Chen, L.; Tong, Y., 2006: Structure-property relationship in chitosan-based biopolymer/montmorillonite nanocomposites. Journal of Polymer Science Part A: Polymer Chemistry, 44: 686-696 http://dx.doi.org/10.1002/pola.20941. 
19. Zeng, Q. H.; Yu, A. B.; Lu, G. Q.; Paul, D. R., 2005: Clay-based polymer Nanocomposites: research and commercial development. Journal of Nanoscience and Nanotechnology, 5: 1574-1592

http://dx.doi.org/10.1166/jnn.2005.411.

20. Zhao, R.; Torley, P.; Halley, P. J., 2008: Emerging biodegradable materials: starch- and protein-based bio-nanocomposites. Journal of Materials Science, 43: 3058-3071 http://dx.doi.org/10.1007/s10853-007-2434-8.

\section{Corresponding address:}

Assoc. Prof. DENIZ AYDEMIR, Ph.D.

Bartin University, Faculty of Forestry Department of Forest Industrial Engineering 74100, Bartin, TURKEY

e-mail: denizaydemir@bartin.edu.tr 